\title{
Geociências
}

\section{New method of semi-automatic modal analyses for phenocrysts of porphyritic rocks based on quantitative digital colour specification technique}

Akihisa Motoki

Depart. de Mineralogia e Petrologia Ígnea, Univ. do Estado do Rio de Janeiro E-mail: rochasornamentais@yahoo.com

Giannis Hans Petrakis

Depart. de Mineralogia e Petrologia Ígnea, Univ. do Estado do Rio de Janeiro.E-mail: giannis.uerj@gmail.com

Rodrigo Soares

Depart.de Mineralogia e Petrologia Ígnea, Univ. do Estado do Rio de Janeiro.E-mail: roddrigoss@yahoo.com.br

Susanna Eleonora Sichel

LAGEMAR, Universidade Federal Fluminense.E-mail: susanna@igeo.uff.br

José Ribeiro Aires

ABAST/Petrobras.E-mail: aires@petrobras.com

\section{Resumo}

O presente artigo propõe um novo método para análise modal de fenocristais e porfiroblastos de tamanho centimétrico a partir de imagem digital. A imagem matricial da rocha é importada para um software de desenho vetorial como background. O contorno de todos os fenocristais é marcado na overlay por curvas vetoriais fechadas, sendo sua área interna pintada em preto. Após esta operação, a imagem da rocha no background é retirada e o background é pintado em branco. Os objetos vetoriais compostos do background e a overlay são exportados como uma imagem matricial de formato BMP. A porcentagem das áreas pintadas em preto corresponde à quantidade modal dos fenocristais e essa quantidade é calculada por software para análise quantitativa de cores Wilbur. Esse método tem alta precisão no processamento gráfico. Entretanto a translucidez da massa fundamental pode causar incerteza na marcação vetorial dos fenocristais. Portanto este método é recomendado para rochas com fenocristais maiores do que $5 \mathrm{~mm}$.

Palavras-chave: Análise modal, imagem digital, fenocristal, porfiroblasto, Wilbur, especificação de cor.

\begin{abstract}
This paper proposes a new method for modal analyses of centimetric phenocrysts and porphyroblasts using a digital rock image. The dot matrix image of the rock is imported into vectorial draw software as background. The outline of all of the phenocrysts is marked on the overlay by closed vectorial curves and their internal area is painted in black. After this operation, the rock image on the background is deleted and the background is painted in white. The vectorial objects composed of the background and the overlay are exported as a matrix image of BMP format. The percentage of the areas painted in black corresponds to modal abundance of the phenocrysts, and it is calculated by the Wilber colour specification software. This method has high precision in graphic processing. However the translucency of the groundmass causes uncertainness in vectorial phenocryst marking. Therefore, it is recommended for rocks with phenocrysts larger than $5 \mathrm{~mm}$.
\end{abstract}

Keywords: Modal analyses, digital image, phenocryst, porphyroblast, Wilbur, colour specification. 
New method of semi-automatic modal analyses for phenocrysts of porphyritic rocks based on ...

\section{Introduction}

The modal amount of phenocrysts is an important parameter for the interpretation of magma crystallisation process of volcanic rocks. The abundance of phenocrysts is measured petrographically by microscopic point counting on thin section. This method, called modal analyses, has high analytical precision. However, some volcanic rocks contain large phenocrysts of the size up to $2 \mathrm{~cm}$, and certain plutonic rocks have phenocrysts larger than 10 $\mathrm{cm}$. Because of the large size, the petrographic accuracy of modal analyses is not so high due to heterogeneous distribution of the phenocrysts and limited area of thin sections, as large as $2 \times 3 \mathrm{~cm}$ (Figure 1).

Some expensive ornamental rocks applied to Brazilian civil construction of plutonic and metamorphic origin are characterised by abundant large phenocrysts or porphyroblasts of alkaline feldspar (e.g. Bahia 1994; Peiter 2001; Erthal et al., 2003). Some of them show cumulative texture, such as porphyritic granite and syenite (e.g. Granito Azul Paramirim, Paramirim - BA, Granito Café Bahia, Riacho de Santana - BA), augen gneiss (e.g. Granito Vermelho Tanquinho, Ichu - BA), and charnockite (e.g. Butterfly Green Granite, Peacock Green Granite, região sul do Espírito Santo). The large phenocrysts of certain rocks show strong blue labradorescence (e.g. Labrador Blue Pearl, Noruega, Blue Star, Roraima). For these rocks, the phenocryst abundance is directly related to their commercial value. The phenocrysts of these ornamental rocks are usually 5 to $15 \mathrm{~cm}$ in size, being much larger than the thin section size, and therefore the conventional modal analyses are useless.

In order to solve this problem, a large area of the rock surface, such as $10 \times 10 \mathrm{~cm}$ for volcanic rocks and $50 \times 50 \mathrm{~cm}$ for granitic rocks, must be analysed using photo images. The quantitative digital colour specification techniques using the software Wilbur (e.g. Motoki et al., 2003a) or Quantikov (e.g. Campello et al., 2005a), combined with manual vectorial marking using vectorial draw software, such as Corel Draw $^{\mathrm{TM}}$ and Adobe Illustrator ${ }^{\mathrm{TM}}$, offer a solution.

The present paper introduces the principle, laboratory procedure, and results of experimental application of this new method for large modal analyses of phenocrysts, and discusses its applicability, possible future development, and limitations.

\section{Quantitative digital colour analyses}

Brazilian production of natural stone is in rapid growth from the beginning of the $21^{\text {st }}$ Century, (Vargas et al., 2005; Motoki et al., 2005a). In order to attend the exigency of international construction market, high-level quality control including their quantitative colour specification became necessary. The methods for colour specification have been developed with the help of the software Wilbur (Motoki et al., 2003a; b; c; 2006; Motoki \& Zucco, 2005) or
Quantikov combined with Spring (Campello \& Costa, 2003; Campello et al., 2004; 2005a; b; Campello, 2006).

Wilbur is an original colour analysing software for dimension stone slabs, which has been developed by Department of Mineralogy and Petrology of Rio de Janeiro State University (DMPI/UERJ; Motoki et al., 2003a). Quantikov is a software for microstructure analysing created by the Brazilian Nuclear Energy Research Institute (IPEN, Pinto 1996). Spring is a geographic information system (GIS) software developed by the Brazilian National Institute of Space Research (INPI; Camara et al., 1996).

The above-mentioned technique analyses physical pixel colours of the rock surface from dot matrix image, either of scanner or of digital camera, and calculates the statistic parameters in RGB, HSB, XYZ, and $x y z$ chromaticity systems. The classification of the ornamental rocks by colour adopts HSB system (Motoki et al., 2003a; b; c; Motoki \& Zucco, 2005; Campello, 2006). It permits high-precision analyses of the dot matrix images of very simplified

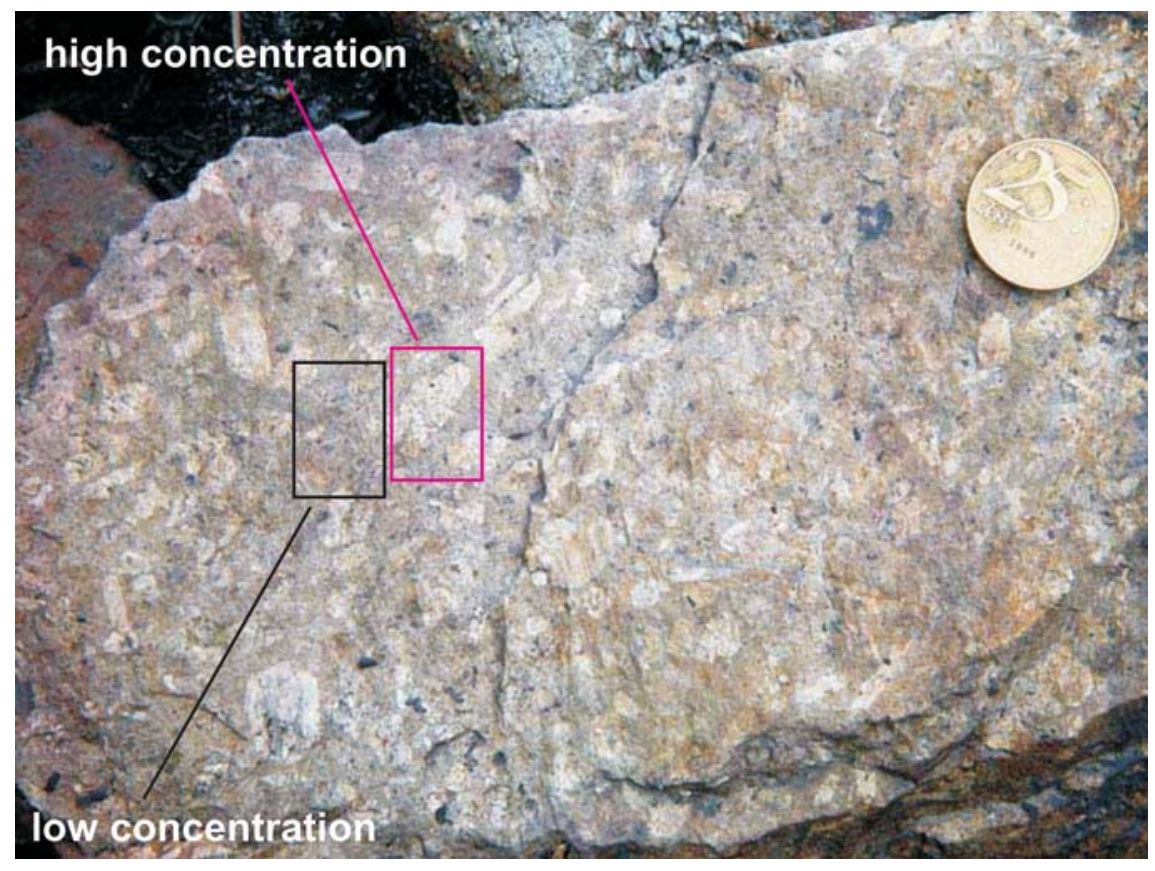

Figure 1 - Field image of porphyritic trachyte of Nova Iguaçu, sample VNI029, after Valente et al. (2005). The red rectangle shows the area of thin section size with high phenocryst concentration, and the black one, with low concentration. 
artificial colours, but the application for mineral modal amount analyses of natural rock images was difficult.

\section{Analytical sequence}

The modal analyses of large phenocrysts are performed by the following steps:

1) Digital image capture.

2) Selection of the area to be analysed.

3) Vectorial marking of the phenocrysts.

4) Digital counting of the painted pixels.

In principle, any types of digital rock image of enough optical resolution can be submitted to this technique. The rock image taken by digital camera in fieldworks must be well focused with optical resolution superior to 2 millions pixels for the object of $50 \mathrm{~cm}$ in size. Application of macro lens is recommended. The rock images are obtained by direct scanning according to Motoki et al. (1999), with optical resolution of 150 to $300 \mathrm{dpi}$.

The rock images, especially of fieldworks, contain useless information, such as vegetation cover, weathered surface (Figure 1), surface streaks, fractures, and organic material stains. Wilbur permits the analyses of selected area excluding these undesired parts (Figure 2). This function is not available for Quantikov and Spring.

The Wilbur requires two BMP files: 1) original rock sample image; 2) the indicator of the area to be analysed, called "selection filter" (Motoki et al., 2005c; d). This filter file is elaborated by the following sequence. The original rock image of any dot matrix format can be imported into the vectorial draw software, such as Corel Draw ${ }^{\mathrm{TM}}$ as background. The area to be analysed is marked by a closed vectorial object on the overlay, and their interior is painted in black. After this operation, the rock image is removed and the background is painted in white. The vectorial objects composed of the white background and the overlay are exported to a dot matrix image file of BMP format. In this operation, anti-aliasing function must be disabled.

The phenocrysts are marked by a similar process to the elaboration of selection filter file. The original image is imported again into the draw software. At this time, the outline of all phenocrysts is marked on the overlay by a closed vectorial curve and their internal area is painted in black. The rock image on the background is removed and the background is painted in white. The white background and the overlay are exported together to a BMP file, without antialiasing function. This file is used as the sample image for the Wilbur.

The Wilbur compares the sample image BMP file and the selective filter one, and counts the number of black and white pixels on the sample image that correspond respectively to the phenocryst and groundmass areas. This operation is performed only on the area indicated by the selection filter. The ratio between the black pixels and the white ones gives modal percentage of the phenocrysts.

\section{Experimental analises}

In order to evaluate the efficiency and accuracy of this technique, the authors performed experimental analyses on the late Cretaceous light-grey porphyritic trachyte of Nova Iguaçu, State of Rio de Janeiro (sample VNI029),
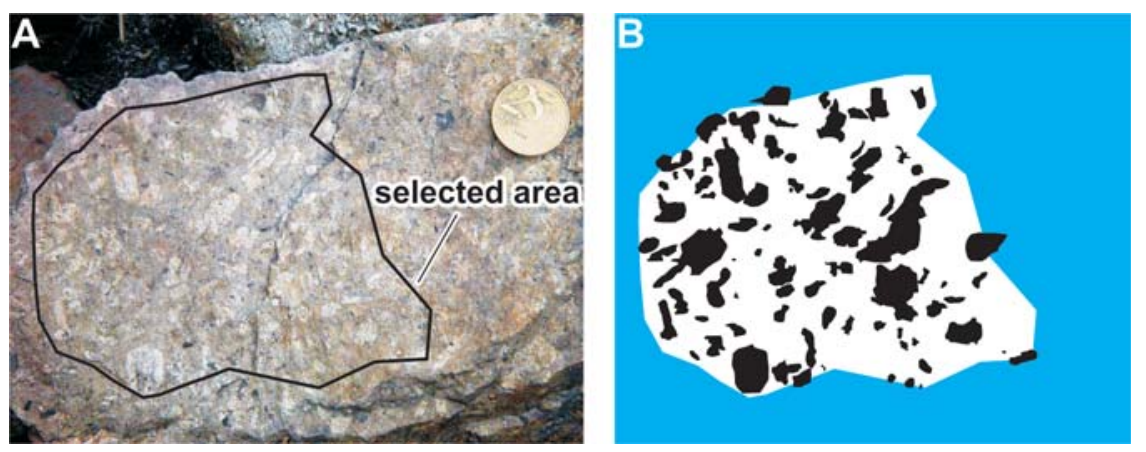

Figure 2 - Image treatments for phenocryst modal analyses before the Wilbur application using vectorial graphic software: A) the area selected for the modal analysis; B) manual vectorial marking of the phenocryst areas.

on the dimension stone slab of an ornamental porphyritic granite (THOR1), and on the photo image (GCB1) published in an dimension stone catalogue of the State of Bahia.”

VNI029 is a photo image of a trachyte block (Figure 1) taken during the fieldwork (Valente et al., 2005). This sample has large phenocrysts, of about $1 \mathrm{~cm}$, therefore the vectorial marking is relatively easy. The horizontal span of the image corresponds to $25 \mathrm{~cm}$. The rock surface is irregular and partially weathered. This image contains some subsurface phenocrysts with ambiguous shape. They must be identified and excluded by subjective decision of the human operator. The modal amount of the alkaline feldspar phenocryst measured by the present technique is $21.9 \%$ (Table 1). It is much less than naked eye estimation, being $40 \%$ according to Valente et al. (2005).

Samples SV1 (Figure 3A) and SV2 (Figure 3D) are scanner images of two different cut surfaces of a small trachyte hand specimen of $7 \mathrm{~cm}$ in size, obtained in 600 dpi and moderated into $300 \mathrm{dpi}$. The areas for modal analyses by means of colour digital specification method are selected by two different criterions: 1) strict selection, eliminating all of weathered areas, SV1A, SV2A (Figure, 3B, E); 2) dull selection, permitting some less altered areas, SV1B, SV2B (Figure $3 \mathrm{C}, \mathrm{F})$. These images are much easier for phenocryst vectorial marking than the outcrop photos.

REM: R. Esc. Minas, Ouro Preto, 60(1): 13-20, jan. mar. 2007 


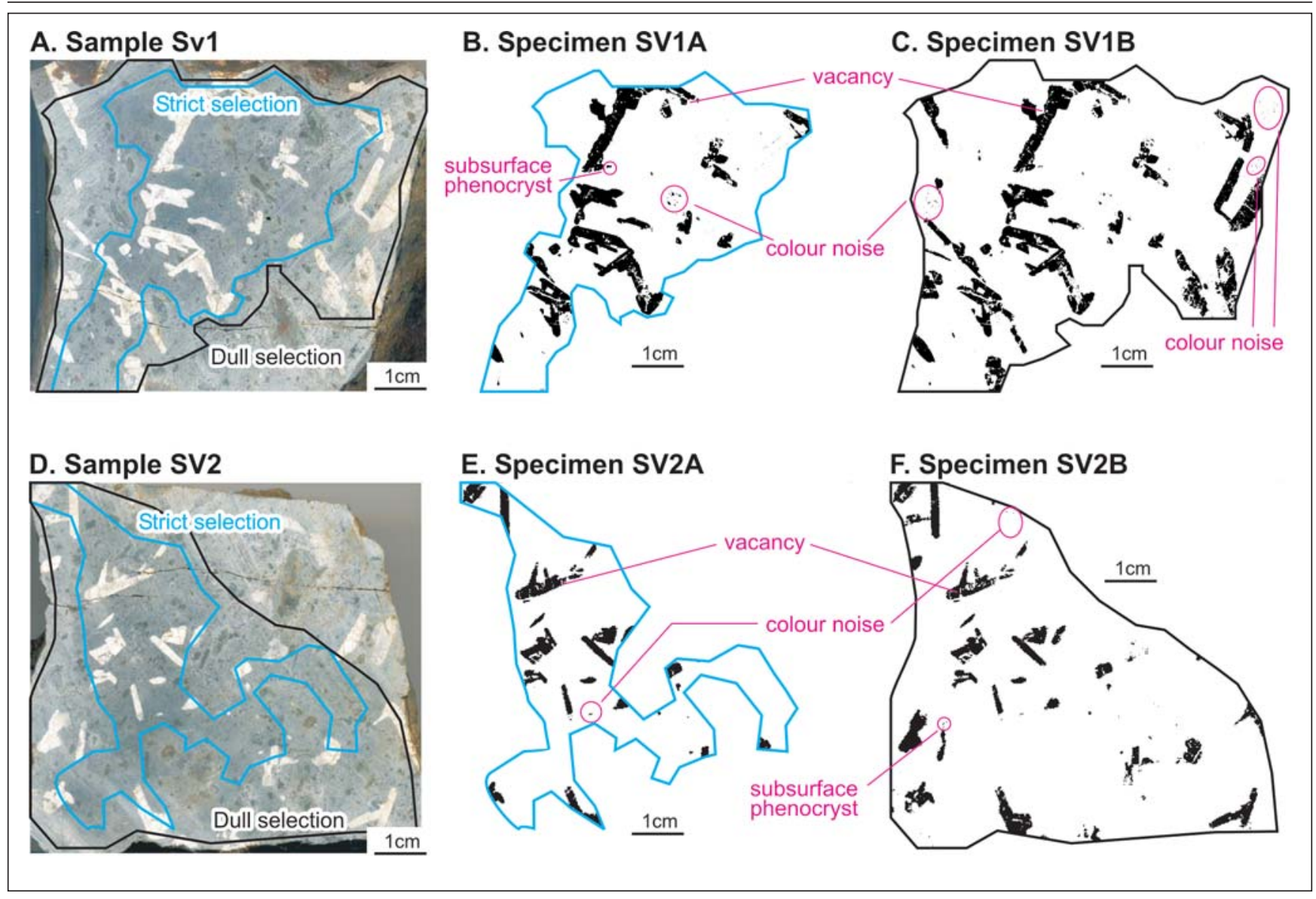

Figure 3 - Selection of the area to be analysed on the cut surface of porphyritic trachyte, samples SV1 and SV2 (A, D): strict selection, specimens SV1A and SV2A, eliminating all of apparently altered areas (B, E); dull selection, specimen SV1B and SV2B, permitting some less altered areas (C, F).

The experimental analyses of these images point out some inconvenient factors. Colour noises on the groundmass originated from rock alteration and subsurface phenocrysts push up improperly the measured modal amount. The vacancy on the phenocryst surface, such as cracks, holes and grooves along the cleavage plane, pull down the value. These factors can be identified easily by sample image observation and must be fixed manually during the vectorial marking.

The measured phenocryst modal amounts of these specimens are widely variable, being $18.6 \%, 17.5 \%, 14.4 \%$, and $11.0 \%$ respectively for SV1A, SV1B, SV2A, and SV2B (Table 1). This variation indicates heterogeneous spatial distribution of the phenocrysts even within a small hand specimen, and the fact is easily recognised by naked eye observation. Such heterogeneous phenocrysts distribution is commonly found in highly porphyritic volcanic rocks, especially those with cumulative texture.

THOR1 is a scanner image of a polished dimension stone of unknown commercial name (Figure 4). This rock slab is characterised by abundant large phenocrysts, as large as $6 \mathrm{~cm} \times 2 \mathrm{~cm}$, showing cumulative texture. The vectorial marking is easy because the rock sample has a smooth surface and is free from weathering, with very large phenocrysts and almost without colour noise. The result is $43.7 \%$ (Table 1 ).

GCB1 is a photo image of porphyritic brown alkaline syenite, called Granito Café Bahia (Figure 5), published in the dimension stone catalogue of the State Government of Bahia (Bahia, 1994).
The rock has abundant phenocrysts of the size up to $5 \times 2 \mathrm{~cm}$, showing cumulative texture. This scanner image is obtained from a photo page of abovementioned book in optical resolution of $600 \mathrm{dpi}$, and strong pixel noise originated from graphic impression is observed. In lower resolution scanning, the pixel noise is intensified showing rainbowcolour. The pixel noise is reduced significantly by means of the moderation of optical resolution to $300 \mathrm{dpi}$ and becomes almost negligible in $150 \mathrm{dpi}$. The modal amount measured for the phenocrysts is $30.4 \%$.

The above-mentioned measured modal amounts are generally less than previous naked eye estimations. For example, Valente et al. (2005) estimated the phenocryst mode of VNI029 to be $40 \%$, however, the measured value by the present method is $21.9 \%$ (Table 1 ). 
Akihisa Motoki et al.

Table 1 - Results of modal analyses by digital colour technique of large phenocrysts.

\begin{tabular}{c|c|c|c|c|c|c}
\hline Specimen & Rock & $\begin{array}{c}\text { Image } \\
\text { type }\end{array}$ & $\begin{array}{c}\text { Analysed } \\
\text { area }\end{array}$ & $\begin{array}{c}\text { Semi- } \\
\text { automatic }\end{array}$ & Automatic & $\begin{array}{c}\text { Manual } \\
\text { correction }\end{array}$ \\
\hline VNI029 & Porphyritic trachyte & Outcrop image & Dull selection & $21.9 \%$ & - & - \\
SV1A & Porphyritic trachyte & Cut surface & Strict selection & $18.6 \%$ & $16.7 \%$ & $16.6 \%$ \\
SV1B & Porphyritic trachyte & Cut surface & Dull selection & $17.5 \%$ & $14.3 \%$ & $16.0 \%$ \\
SV2A & Porphyritic trachyte & Cut surface & Strict selection & $14.4 \%$ & $11.1 \%$ & $12.2 \%$ \\
SV2B & Porphyritic trachyte & Cut surface & Dull selection & $11.0 \%$ & $7.8 \%$ & $8.8 \%$ \\
THOR1 & Porphyritic granite & Polish surface & Whole rock & $43.7 \%$ & - & - \\
GCB1 & Porphyritic syenite & Photo on book & Whole rock & $30.4 \%$ & - & - \\
\hline
\end{tabular}

The fact means that the visual impression is much larger than the real modal amount of the phenocrysts.

\section{Attempt of automatic analyses}

Certain volcanic rocks have strong colour contrast between kaolinised white alkaline feldspar phenocrysts and vitric or hypocrystalline dark groundmass (Figure 3A). Such rocks, for example the specimens SV1A, SV1B, SV2A, and SV2B, are analysed by automatic processes, which needs no manual vectorial marking. The area is marked automatically by computer based on the colour difference between the phenocryst and the groundmass.

The phenocrysts of these specimens have the $\mathrm{B}$ parameter, that is, brightness of the HBS chromaticity system, superior to 95 , with strong peak at $B=100$ on the histogram. In contrast, the $\mathrm{B}$ parameter of the groundmass is distributed in a range of $40 \sim 75$, and its mode is present at $B=57$. Because of the well-distinguished bimodal pattern (Figure 6A), automatic selection of the phenocryst area seems to be possible.

On the other hand, B histograms pattern for non-kaolinised rocks, VNI026,

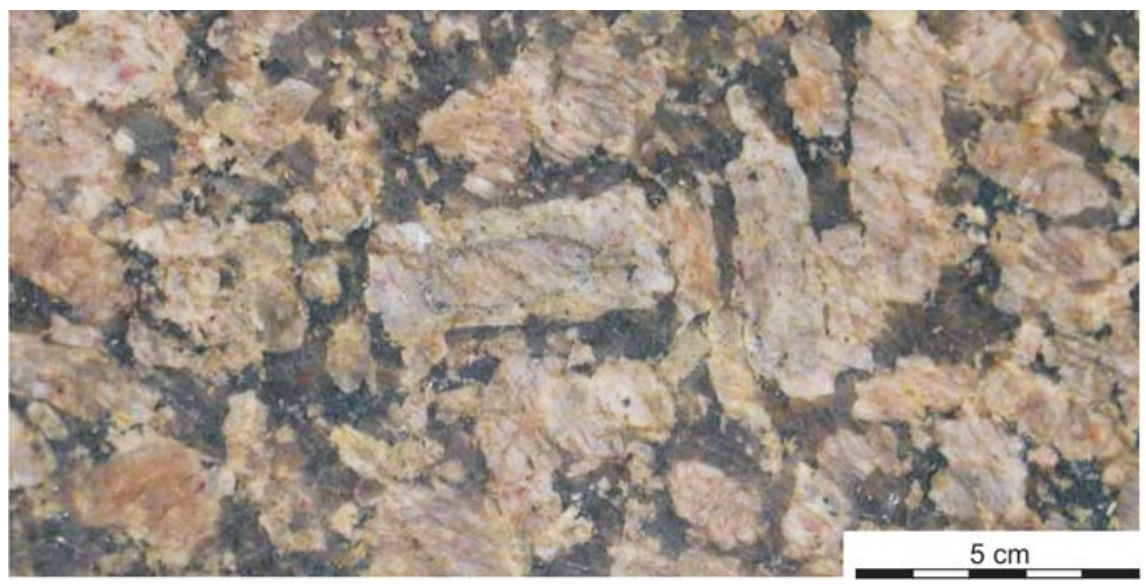

Figure 4 - Porphyritic granite with cumulative large phenocrysts of an ornamental rock of unknown commercial name, sample THOR1.

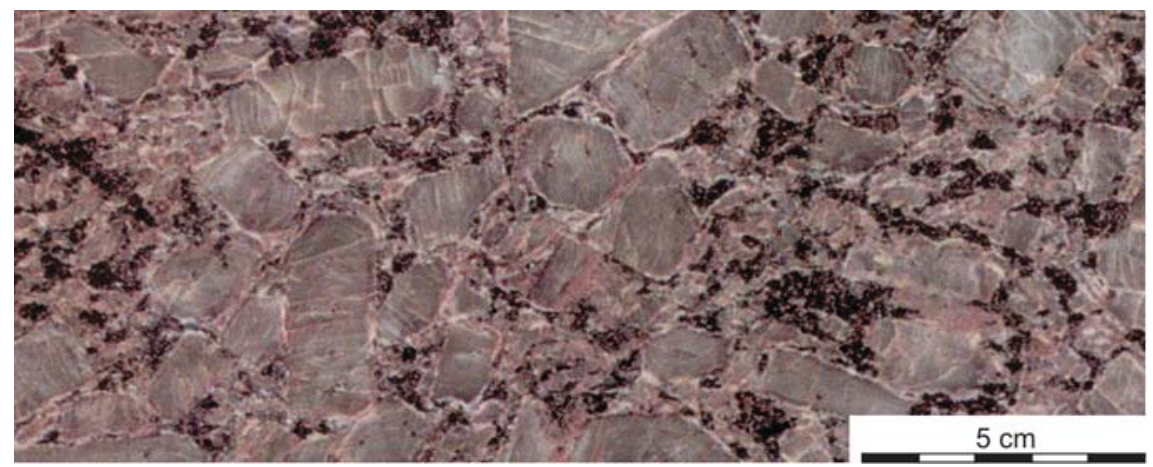

Figure 5 - Scanner image of Granito Café Bahia obtained from a photo page of Bahia (1994), sample GCB1. 


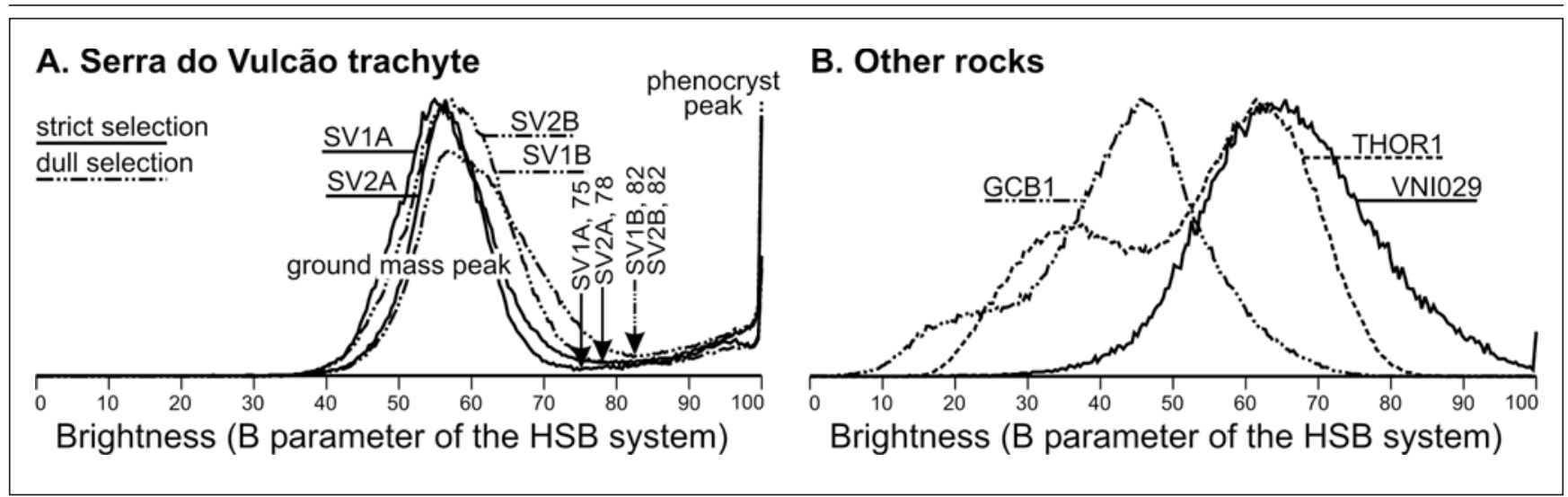

Figure 6 - Brightness histogram, that is, B parameter of the HSB chromaticity system, for the specimens of kalinised porphyritic trachyte specimens of the Serra do Vulcão, Nova Iguaçu, State of Rio de Janeiro, SV1A, SV2A, SV1B, and SV2B (A) and the histogram for the other rock samples, VNI029, THOR1, and GCB1 (B).

THOR1, and GCB1, are unimodal or lessexpressively bimodal (Figure 6B). Because of the ambiguous criterion, it is difficult to make software for the phenocryst area selection.

In the automatic process, mineral identification is less precise than manual vectorial marking because the phenocrysts are identified only by its colour. In spite of above-mentioned problem, the automatic method is highly attractive, being easy, rapid and independent on the petrographic skill of the operator.

On the B histograms of strictly selected specimens, SV1A and SV2A, the peaks either of the phenocrysts or of the groundmass are acute, and the dip between the two peaks is low. The groundmass peak is highly symmetric, being similar to the Gauss distribution. However, on the B histogram of dullselected specimens, SV1B and SV2B, the groundmass peak is not so acute. This fact is attributed to high-level colour noise on the groundmass of these specimens. Obviously, the data of strictly selected specimens, SV1A and SV2A, have higher analytical reliability, however they could be less accurate because of the limited area for colour analysis. In the case of manual vectorial marking, this problem is not so critical.

The B value for the threshold in order to distinguish phenocryst pixels and of groundmass ones is selected at the lowest point of the dip between the two peaks (Figure 6). They are 78, 82, 75, and 82 respectively for the specimens SV1A, SV1B, SV2A, and SV2B. The phenocryst modal amounts measured by computer are $16.7 \%, 14.3 \%, 11.1 \%$, and $7.8 \%$ respectively for SV1A, SV1B, SV2A, and SV2B (Table 1).

Figure 7 shows comparatively the details of: A) the original rock surface; B) the pixels with $B$ superior to 78 ; $C$ ) the ones with $B$ superior to 82 . The effect of the threshold value selection is critical. High threshold reduces the groundmass colour noise but enlarge the cavities on the phenocryst surface. On the contrary, low threshold reduces the cavity problem but amplifies the groundmass colour noise. Because of the kaolinization, the phenocryst surface inevitably has cavities and the groundmass always has colour noise. These factors are harmful for analytical precision of the automatic method.

The images of the phenocryst area marked by automatic process of the computer (Figure 7B, C, E, F) show the cavities present on the phenocryst surface and the colour noise on the groundmass, and they are easily identified even for the beginners. Therefore, the analytical accuracy could be improved by manual correction. According to the subjective decision of the operator, the holes and cavities on the mineral surface are manually filled and the colour noise on the groundmass is cleaned using the brush tool and pencil tool of Adobe Photoshop ${ }^{\mathrm{TM}}$ or Corel Photopaint $^{\mathrm{TM}}$ (Figure 7D). In this case, the threshold value selection is not so critical. The results are $16.6 \%, 16.0 \%$, $12.2 \%$, and $8.8 \%$, respectively for SV1A, SV1B, SV2A, and SV2B (Table 1). The results of automatic modal amounts are significantly lower than the semiautomatic method.

The difference may be due to the alteration of the phenocrysts. Because of mineral alteration, many cavities, such as holes and grooves, are formed along the rim and cleavage planes, which cause underestimation of measured value (Figure 8). The cleavage effect can be fixed by the manual operation, however the rim effect, called "marginal loss", is difficult to be corrected. Therefore, the measured modal amount by the automatic analyses tends to be lower than the real one. These observations suggest that the automatic methods are less accurate than the semi-automatic method.

\section{Discussion}

The semi-automatic phenocryst modal analyses can process more than 1 millions pixels for each specimen. This number is larger than conventional modal analyses, usually involving counting from 1000 to 5000 points. This large number of analysed pixels contributes, at least partially, to petrographic accuracy improvement. 


\section{Sampel SV1}

\section{A. original image}

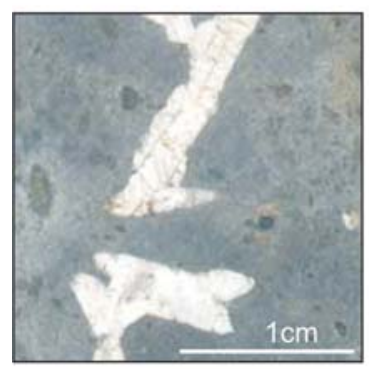

\section{Sampel Sv2}

\section{A. original image}

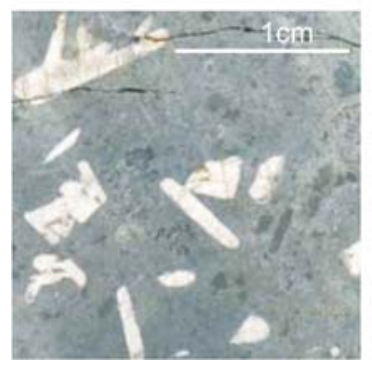

B. Specimen SV1A, threshold $=75$

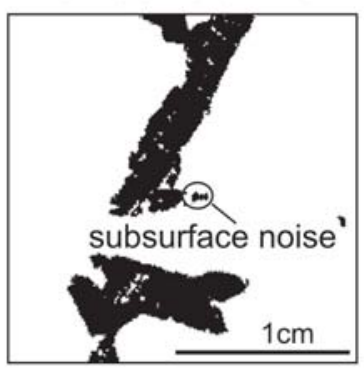

C. Specimen SV1B

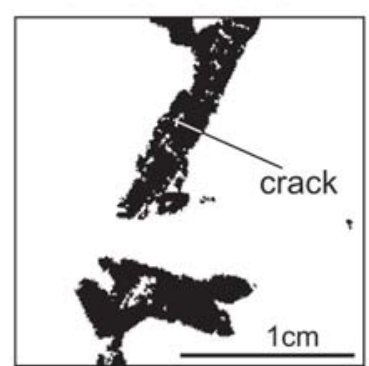

D. manual correction

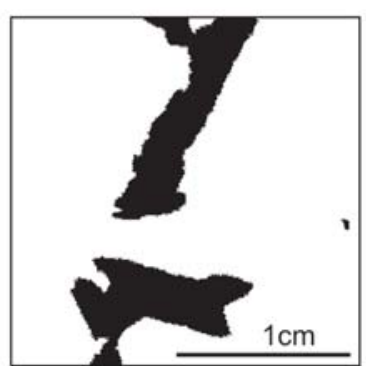

B. Specimen SV2A, threshold $=78$

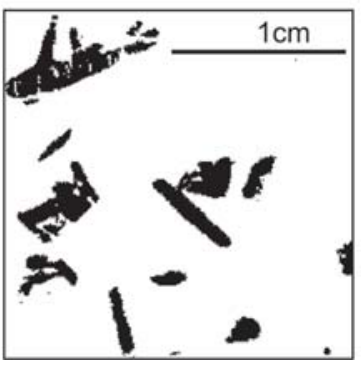

C. Specimen SV2B threshold $=82$

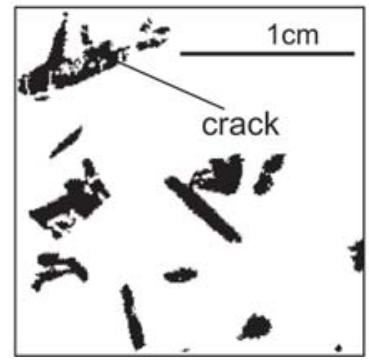

D. manual correction

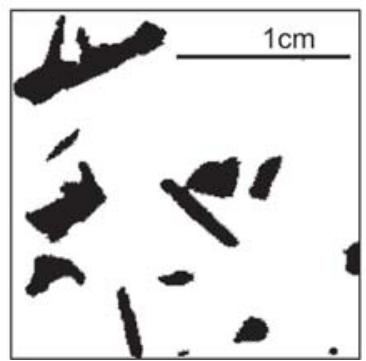

Figure 7 - Natural rock image and computer treated ones of SV1 (A, B, C, D) and SV2 (E, F, G, H): (A, E) Original colour image of the cut surface; (B, F) Computer output image of selected pixels for the specimens of strict selection, SV1A, SV2A; (C, G) those for the specimens of dull selection, SV1B, SV2B; (D, H) Manually corrected image form the $B, F$.

On the other hand, the experience of the experimental analyses points out two technical problems: 1) mineral identification accuracy; 2) translucency of the groundmass. The phenocrysts are identified only by macroscopic rock image, therefore optical properties, such as interference colour, relative refraction index, extinction angle, pleochroism, and conoscopic interference figure are not available. In this sense, petrographical skill of the operator is important. The rocks with relatively small phenocrysts sometimes show serious problems of translucency of the groundmass, emerging the phenocrysts situated in subsurface as dull-focused image. (Figure 7A, B; 8). These crystals cause overestimation of the modal amount and therefore must be excluded by subjective decision of the operator. These unfavourable factors appear notably in

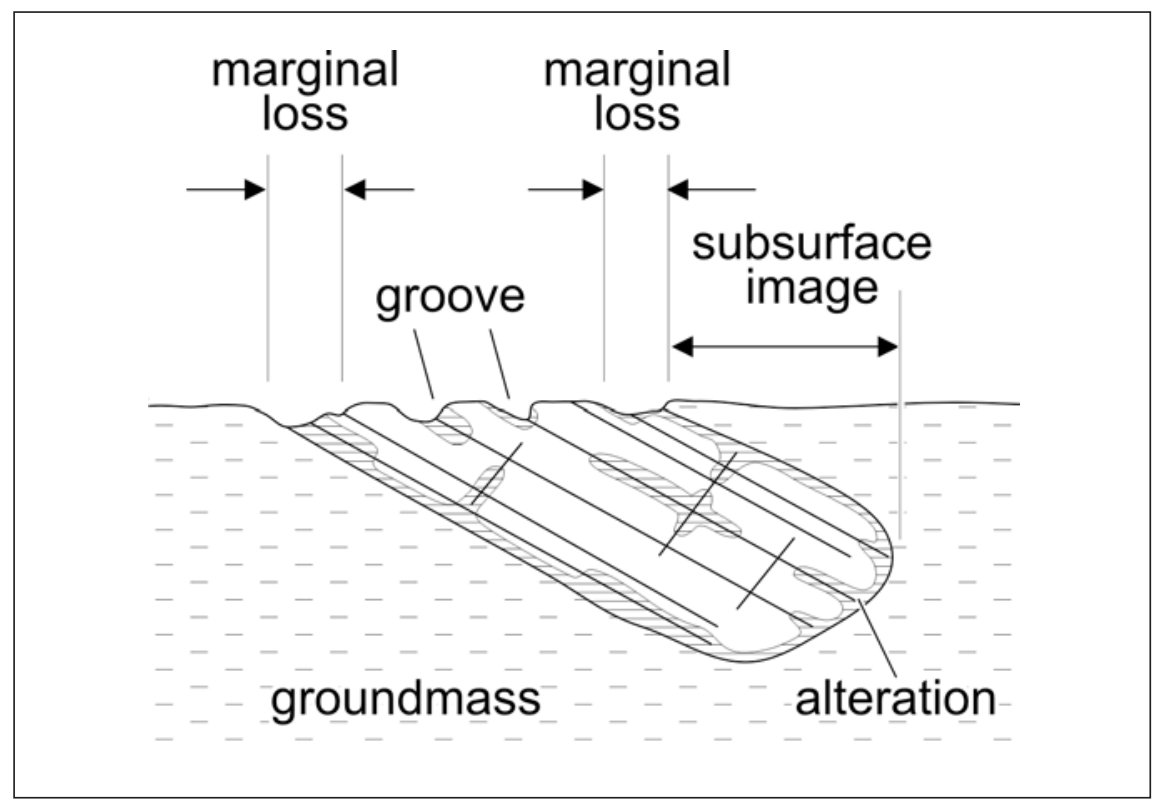

Figure 8 - The factors present on rock surface harmful for automatic modal amount analyses: grooves along cleavage planes and marginal loss that cause underestimation; subsurface mineral image that makes overestimation. 
case of the rocks with small phenocrysts. On the contrary, in case of phenocrysts larger than $1 \mathrm{~cm}$, these problems are not critical.

Consequently, the present method is applicable for the rock with phenocrysts at least larger than $2 \mathrm{~mm}$, in practice larger than $5 \mathrm{~mm}$. The rocks with small phenocrysts should be analysed by thin section. The application of this method for thin section is in development.

\section{Conclusion}

The modal amount of large phenocrysts, from $5 \mathrm{~mm}$ to 10 $\mathrm{cm}$ in size, can be obtained with the help of the semi-automatic analyses from a digital rock image that covers an area larger than $100 \mathrm{~cm}^{2}$. The proposed method is applied to all types of digital rock images, such as field outcrop photograph, unpolished cut surface by diamond saw, polished surface of dimension stone slabs and rock images extracted from books and pamphlets. The precision of graphic analysis is very high because of the large number of pixels analysed, much more than 1 million. The petrographic accuracy is dependent on the manual and subjective processes, requiring petrographical skill of the operator. Because of partial translucency of the groundmass, this method is recommended for the phenocrysts larger than $5 \mathrm{~mm}$. At this moment, the semi-automatic analyses is more practical and accurate than the automatic process. The measured modal amount is generally less than previous visual estimation.

\section{Acknowledgement}

The authors are grateful to Prof. José Luiz Peixoto Neves, of the Department of Mineralogy and Petrology of the Rio de Janeiro State University for helpful advice and Mr. Sócrates Giannis Petrakis of Partenon Mármores, Rio de Janeiro, State of Rio de Janeiro, for treatment of some samples.

\section{Reference}

BAHIA. Catálogo de rochas ornamentais da Bahia-Brasil. Secretaria da Indústria Comércio e Turismo do Estado da Bahia, SGM, 1994.

CAMPELLO, M.S. Técnicas de processamento digital de imagens com aplicação no setor das rochas ornamentais. Instituto de Geociências da Universidade Federal de Minas Gerais, 2006. 165p. (Tese de doutorado - unpublished).

CAMPELLO, M.S., BRUNO, R., COSTA,A.G., MOURA, A.C. Proposta de classificação das rochas ornamentais com base em parâmetros estéticos. In: International Congress of Dimension Stones (ICIRO), 1. Ann... Guarapari, 2005a. CD.

CAMPELLO, M.S., COSTA, A.G. Desenvolvimento de metodologia para o emprego de Quantikov - software analisador de imagens, na determinação da análise modal tipos pétreos com valor comercial. Boletim de Resumos do Simpósio Regional de Geologia de Minas Gerais, 2003. CD.

CAMPELLO, M.S., COSTA, A.G., BRUNO, R., MOURA, A.C., PINTO, L.C.M. Proposta de classificação das rochas ornamentais com base em parâmetros estéticos. In: Congresso Brasileiro de Geologia, 42. Anais... Araxá: SBG, 2004. CD.
CAMPELLO, M.S., COSTA, A.G., MOUORA, A.C., FREITAS, C.R., PINTO, L.M. Técnica de processamento digital de imagens para correlação entre a forma dos grãos e característica tecnológica de granitos ornamentais. Bol. Res. $9^{\circ}$ Simp. Reg. Geol. Sudeste, $13^{\circ}$ Simp. Reg. Geol. Minas Gerais. Niterói: 2005b. CD.

ERTHAL, F.E., MANSUR, K., NUNES, H., PUGET, A. Rochas ornamentais do Estado do Rio de Janeiro. DRM-RJ, 2003. 30p.

MOTOKI, A. The Inada Granite, Japanese traditional light-grey ornamental rock. Litos. Madrid: Special Chinese Edition, 2005. p. 46-56.

MOTOKI, A., VARGAS. T., NEVES, J.L.P., ZUCCO, L.L. Pietri naturari classificate per colori, una técnica de misurazione quantitativa del colore per rocce ornamentali e semi-ornamentali, utilizzando scanner e computer. L'Informatore del Marmistas, Milano, v. 493, p. 6-16, 2003 a.

MOTOKI, A., VARGAS. T., NEVES, J.L.P., ZUCCO, L.L. Quantitative analyses of rock and mineral surface color for ornamental and semi-ornamental rocks using image scanner. Japanese Magazine of Mineralogical and Petrological Sciences, Sendai, v. 32, n. 1, p. 12-22, 2003b.

MOTOKI, A., ZUCCO, L.L, VARGAS, T., SICHEL, S.E., NEVES, J.L.P., AIRES, J.R. Especificação digital de cores com o auxílio de scanner e computador e classificação quantitativa de rocha ornamentais com objetivo de controle de qualidade de alta precisão por meio de parâmetros de cores físicas. In: Simpósio Brasileiro de Geofísica, 3. Natal: 2006. CD. 6p.

MOTOKI, A., ZUCCO, L.L. Digital colour specification for ornamental rocks using image scanner: its technical challenge, on-going development, further innovation, and application. In: International Congress of Dimension Stones (ICIRO), 1. Ann... Guarapari: 2005. CD. 6p.

MOTOKI, A., MELO, D.P. Extraction, reforming and applications of the Inada Granite, a traditional Japanese ornamental rock of light grey colour. In: International Congress of Dimension Stones, 1.Ann... Guarapari: 2005. CD. 7p.

MOTOKI, A., NEVES, J.L.P., VARGAS, T. Digital specification of whole-rock and spot colours of Mármore Bege Bahia, a Brazilian light yellow limestone of breccia texture. In: International Congress of Dimension Stones, 1. Ann... Guarapari: 2005d. CD. 6p.

MOTOKI, A., NEVES, J.L.P., VARGAS, T. Quantitative colour analyses using digital specification technique for Mármore Bege Bahia, a representative Brazilian ornamental limestone of breccia-like texture. Revista Escola de Minas, v. 58, n. 2, p. 113-120, 2005c.

MOTOKI, A.; VARGAS, T.; ZUCCO, L.L. El basalto, piedra semi-ornamental brasileña. Litos, Madrid, v. 66, p. 52-63. 2003d.

MOTOKI, A., VARGAS, T., ZUCCO, L.L., NEVES, J.L.P., SILVA, M., FREITAS, A., MELO, D.P.Classificação de rochas ornamentais por meio de medida quantitativa de cores com o auxílio de scanner. Bol. Res. 8 $^{\circ}$ Simpósio de Geologia do Sudeste, São Pedro, p. 197, 2003c.

MOTOKI, A., ZUCCO, L.L., FREITAS, A. Ornamental and artistic applications of Basalt, an attractive variation of porphyry of south-most Brazil, with special attention of its colour variation. In: International Congress of Dimension Stones, 1. Ann... Guarapari: 2005a. CD. 6p.

MOTOKI, A., ZUCCO, L.L., SALIBA, F. Caracterização das cores do Basalto da Serra Gaúcha por meio da técnica de especificação quantitativa digital por scanner. Boletim de Resumos do $9^{\circ}$ Simpósio de Geologia do Sudeste, $13^{\circ}$ Simpósio de Geologia de Minas Gerais, Niterói, p. 99, $2005 \mathrm{~b}$.

MOTOKI, A., VARGAS, T., ZUCCO, L.L., PEIXOTO, J.L.N., CARIO, F.D., MOTOKI, K.F. Captura direta de imagens macroscópicas de rochas via scanner. Mineração Metalurgia, v. 552, p. 25-30, 1999.

PIETER, C.C. Rochas ornamentais no século XXI. CETEM/ABIROCHAS, 2001. 160p.

PINTO, L.C.M. Um analisador microestrutural para o ambiente Windows ${ }^{T M}$. Universidade de São Paulo-USP, IPEN, 1996. (Tese de Doutorado unpublished).

VALENTE, S.C., MELLO, E.F., PALERMO. Geologia de uma porção do complexo vulcânico de Nova Iguaçu limítrofe à área de lavra da pedreira Vigné, Nova Iguaçu, RJ. Relatório final. Nova Iguaçu: Ministério Público, 2005. 72p.

VARGAS, T., MOTOKI, A., NEVES, J.L.P. Academic diffusion of natural stone science and technology in brazilian elementary and high schools in order to motivate ornamental rock application and future market growth. In: International Congress of Dimension Stones, 1. Ann... Guarapari: 2005. CD. 6p.

Artigo recebido em 06/07/2006 e aprovado em 22/11/2006. 